\title{
Next-Generation Cancer Vaccine Approaches: Integrating Lessons Learned From Current Successes With Promising Biotechnologic Advances
}

Dung T. Le, MD, and Elizabeth M. Jaffee, MD

\begin{abstract}
With the recent approval of sipuleucel-T for metastatic castrationresistant prostate cancer and ipilimumab for metastatic melanoma, there is increasing excitement in the field of cancer immunotherapy. A large number of clinical trials are currently testing various vaccine vectors in a diverse array of cancer types. Which of these strategies will ultimately prove successful has yet to be determined. However, a better understanding of the complex interplay of tumor-specific $T$ cells and the challenges faced at the tumor microenvironment, advances in biotechnology, and lessons learned from prior successes and failures will likely lead to approvals of other therapeutic cancer vaccines. (JNCCN 2013;11:766-772)
\end{abstract}

$\mathbf{W}_{\text {ith the approvals of sipuleucel-T and ipilimumab, }}$ immunotherapy has become a treatment option for more oncology patients. Sipuleucel-T is an autologous cellular product immunotherapy used to prime tumor antigen-specific $\mathrm{T}$ cells, and ipilimumab targets cytotoxic T-lymphocyte antigen 4 (CTLA-4) on activated $\mathrm{T}$ cells to block negative signals to the $\mathrm{T}$ cell. ${ }^{1-7}$ Future successes are predicted as a result of blocking a second T-cell inhibitory signaling pathway, programmed death-1 (PD-1) and its ligand PD-L1. ${ }^{8-10}$ Furthermore, vaccination with patient-specific hybridoma-derived

From The Sidney Kimmel Comprehensive Cancer Center at Johns Hopkins University School of Medicine, Baltimore, Maryland.

Submitted November 26, 2012; accepted for publication

May 9, 2013.

Dr. Le has disclosed that she has no financial interests,

arrangements, affiliations, or commercial interests with the manufacturers of any products discussed in this article or their competitors. Dr. Jaffee has dislosed that she has the potential to receive royalties related to GVAX.

Correspondence: Dung T. Le, MD, The Sidney Kimmel Comprehensive Cancer Center at Johns Hopkins University School of Medicine,

1650 Orleans Street, Room 407, Baltimore, MD 21287.

E-mail: dle2@jhmi.edu idiotype vaccine may prolong disease-free survival in patients with follicular lymphoma after chemotherapyinduced remission, ${ }^{11}$ and a survival benefit was seen for patients with advanced melanoma treated with gp100 peptide vaccine plus high-dose interleukin 2 (IL-2) over those treated with IL-2 alone. ${ }^{12}$ Importantly, the success of sipuleucel- $\mathrm{T}$ for prostate cancer and the predicted success of agents that block the PD-1/PD-L1 pathway for non-small cell lung cancer (NSCLC) challenges for the first time the dogma that immunotherapy will only be successful against immunogenic cancers like malignant melanoma. In addition, immune checkpoint inhibitors have received increasing attention because of their ability to produce actual tumor regressions, challenging the long-held belief that immunotherapy will only work well in patients with minimal residual disease. ${ }^{5,6,8,10}$ Acceptance of therapeutic vaccines, however, continues to be hampered by questionable proof of activity as single agents. Schlom ${ }^{13}$ recently provided an excellent summary of current vaccine platforms, targets, trial design, combinatorial strategies, biomarkers, and future approaches. This article expands on the discussion of recent immunotherapy successes and highlights new advances that will undoubtedly lead to future clinical successes.

\section{Sipuleucel-T}

In 2010, the FDA approved sipuleucel-T for the treatment of metastatic castration-resistant prostate cancer (mCRPC) based on an improvement in overall survival (OS) from 21.7 to 25.8 months over placebo (hazard ratio $[\mathrm{HR}], 0.78 ; \mathrm{P}=.03) .{ }^{1}$ The product is generated using patient's cells as the source of the antigen-presenting cells (APCs) obtained through leukapheresis. Enriched 
monocytes are incubated with a construct that fuses prostatic acid phosphatase (PAP) with granulocytemacrophage colony-stimulating factor (GM-CSF)., The PAP serves as the tumor antigen and the GMCSF targets the antigen to the APC while simultaneously providing maturation signals. The vaccine is then administered biweekly for 3 doses. The OS benefit seen in the phase III trial was demonstrated despite lack of improvement of progression-free survival (PFS) in any of the studies. ${ }^{1}$ Other concerns included the use of patients with advanced disease and prior therapies; the targeting of a single antigen, which might result in selective pressure and antigen escape; the technical limitations of this complex approach, which limits the ability to continue boosting; and the use as a single agent without targeting any of the postulated immune inhibitory mechanisms in the periphery or the tumor microenvironment. Despite these concerns, sipuleucel-T proved to be efficacious.

Recent studies have shown that RECIST responses and effects on progression cannot substitute for OS in immunotherapy trials. ${ }^{1,14}$ This has been best demonstrated in the sipuleucel- $T$ trial and the ipilimumab trials in melanoma showing no effects on PFS but showing an OS benefit, which led to the approval of each agent in their respective indications. ${ }^{1,6,14}$ A recent study evaluated tumor growth rates in prostate cancer in 4 chemotherapy trials and 1 vaccine trial using the PSA-Tricom vaccine, which expresses transgenes for prostate-specific antigen (PSA) and costimulatory molecules (B7.1, ICAM-1, and Lfa-3). ${ }^{15}$ With chemotherapy, tumors can regress, but once resistance develops, the growth rate returns to baseline. For the PSATricom vaccine, deceleration of tumor growth rate occurred, which showed no effect on response rate or PFS but improved OS. ${ }^{15-17}$ Although the concept of continued, albeit slower, growth can be unsettling to providers and patients, this strategy can be used in a cancer indication in which the median survival is relatively long even in the control group (22 months). ${ }^{1}$ Because immunotherapy works on the immune system and a delayed effect is expected, RECIST may not be reliable. However, the converse is also true that objective responses provide assurance when applying this philosophy to individual patients. In fact, objective PSA effects were seen using sipuleucel-T, and imaging stabiliza- tion, response, and delayed response were seen with ipilimumab. However, these responses were often not considered responses based on standard definitions. These clinical signs do support the potential efficacy of these agents.

In addition to using OS as the primary objective, the patient population was also critical to the success of this trial. These patients had minimally symptomatic disease. Again, even in mCRPC, the median survival in the control group was 22 months, which points to the relatively indolent nature of the disease. In a phase II trial of the PSA-Tricom vaccine, ${ }^{18} \mathrm{pa}-$ tients who were predicted to have indolent disease using the Halabi prediction nomogram ${ }^{19}$ lived a median of more than 37.3 months. This suggests that if the kinetics of tumor growth outpace the kinetics of immune induction, then immunologic treatments are unlikely to be successful. Many trials are now limiting patient populations to earlier-stage disease, such as resected disease, marker-only elevations, or localized (not yet metastatic) cancer. The growth rate in metastatic disease clearly depends on the disease biology of the various cancer types, but certainly trying to limit the patient population to those with lower-burden metastatic disease may also improve outcomes. A maintenance strategy in patients whose disease responds to chemotherapy could also be envisioned in several disease types (NSCLC and colon and pancreatic cancers). Theoretically, the adjuvant setting may seem the most ideal for immunotherapy; however, definitive results thus far have only been seen in metastatic disease. It is possible that more-active agents may play a role in this setting in the future, or that perhaps choosing patients at very high risk for recurrence is similar to choosing patients with less-indolent disease.

Two additional features of study design may have contributed to the success of sipuleucel-T but the failure of another prostate cancer vaccine, GVAX (allogeneic prostate cancer cells modified to express GM-CSF). In the Vaccine Immunotherapy with Allogeneic Prostate Cancer Cell Lines (VITAL)-1 study, men with asymptomatic mCRPC received GVAX or docetaxel plus prednisone, which is a therapy that has shown activity in symptomatic mCRPC. ${ }^{20}$ In contrast, the placebo in the sipuleucel-T study was APCs cultured in media. ${ }^{1}$ GVAX actually fared well in this trial. However, the trial did not meet the end point of establishing superiority over an effective therapy. The median survival was 
Le and Jaffee

20.7 versus 21.7 months (GVAX vs chemotherapy; HR, 1.03 ; 95\% CI, 0.83, 1.28; $P=.78$ ), with a lower grade 3 adverse event rate in the GVAX arm (8.8\% vs $43.0 \%)$. Furthermore, the Kaplan-Meier curve shows GVAX crossing over to chemotherapy at 22 months.

The VITAL-2 study tested GVAX plus docetaxel versus docetaxel plus prednisone in symptomatic mCRPC. ${ }^{21,22}$ Not only was this study performed using an active comparator, but also the experimental arm of full-dose immunosuppressive chemotherapy plus vaccine had not been previously tested. This is not to say that newer, potentially expensive agents should not have a high bar to cross, but to point out that trial design can influence outcomes.

\section{Update on Selected Vaccine Vectors}

At the center of every vaccine approach is the delivery of tumor antigen to APCs, which will ultimately orchestrate the immune response. Antigen delivery must occur in the context of other immune stimulatory signals or the result will favor a tolerogenic response over an immunogenic one. Strategies range from providing peptides in combination with immune adjuvants, to ex vivo loading of antigen on APCs that have been provided additional maturation signals (eg, GM-CSF, IL-4; Table 1). These ex vivo strategies are cumbersome and technically difficult, and limit immune-boosting capabilities. Peptide strategies are the simplest in terms of manufacturing, administration, and quality control, and could easily be adapted to target multiple antigens, but they lack efficiency in terms of antigen delivery to the APC. However, a few other strategies are in phase II and III development with large-scale capacity that have the potential for multiepitope targeting with simultaneous delivery of maturation signals to APCs. Viral and bacterial vectors are particularly interesting because of their inherit capacity to deliver "danger signals" and antigens directly to APCs. These vectors engage toll-like receptors (TLRs) and other pattern recognition receptors (PRRs) that recognize pathogen-associated molecular patterns. However, even with the most effective vectors, the choice of antigen may not be relevant. As one way to address this issue, some vectors allow integration of multiple antigens. Furthermore, targeting a few antigens may, through epitope spreading, result in a broader antitumor response. The previously men- tioned PSA-Tricom vaccine is a combination of a vaccinia prime followed by fowlpox boosts, both of which express transgenes for PSA and costimulatory molecules (B7.1, ICAM-1, and Lfa-3). This sequential strategy reduces immune-mediated viral neutralization. A phase II randomized trial showed an improvement in OS of 8.5 months over placebo, ${ }^{17}$ which led to an ongoing phase III study in minimally symptomatic mCRPC (ClinicalTrials.gov identifier: NCT01322490). Live-attenuated Listeria monocytogenes $(\mathrm{Lm})$ strains are also undergoing testing in several phase III studies. Listeria is an obligate intracellular organism that targets dendritic cells (DCs) and monocytes and delivers antigen into both the major histocompatibility complex class I and II antigen processing pathway, resulting in activation of both $\mathrm{CD}^{+}$and $\mathrm{CD}^{+} \mathrm{T}$ cells. It stimulates innate immunity and, through stimulation of TLRs and other PRRs, works as its own adjuvant. Repeated vaccinations do not result in neutralization, and the construct can be designed to express multiple tumor antigens. Two different $L m$-based vaccine platforms have advanced into phase II clinical trials in pancreatic $^{23}$ (ClinicalTrials.gov identifier: NCT01417000) and cervical cancers ${ }^{24}$ (ClinicalTrials.gov identifier: NCT01266460).

The safety and feasibility of intravenous administration of the $\mathrm{L}$ monocytogenes wild-type vaccine (ANZ-100) and the $L m$ vaccine modified to deliver the pancreatic tumor antigen mesothelin (CRS-207) have been reported, with $1 \times 109$ colony-forming units as a safe and bioactive dose. ${ }^{23}$ Evidence showed immune activation as measured by chemokine and cytokine levels, and natural killer cell activation. The CRS-207 study was performed in subjects with treatment-refractory cancers known to express mesothelin (mesothelioma and pancreatic, ovarian, and lung cancers). Of 17 subjects, 6 treated with the $\mathrm{Lm}$-mesothelin vaccine survived for 15 or more months; $100 \%(5 / 5)$ of evaluable long-term survivors had vaccine-induced $L m$-specific immunity versus $33 \%(1 / 3)$ who did not survive 15 months. Mesothelin-specific T-cell responses were detected in 6 of 10 patients. Preclinical models show that Lm-based vaccines work effectively as a boosting strategy to several different vaccines (D. Brockstedt, $\mathrm{PhD}$, unpublished data, 2011). A randomized phase II study testing CRS-207 as a boost to pancreatic GVAX in patients with advanced pancreatic cancer has com- 


\begin{tabular}{|c|c|c|c|c|c|c|}
\hline Vaccine & Vector (Antigen) & Indication & Population & Treatment Arms & Trial Identifier & End Point \\
\hline \multicolumn{7}{|l|}{ Phase III } \\
\hline PROSTVAC & $\begin{array}{l}\text { Vaccinia/fowlpox } \\
\text { viruses (PSA) }\end{array}$ & mCRPC & $\begin{array}{l}\text { Chemotherapy- } \\
\text { naïve, minimally } \\
\text { symptomatic }\end{array}$ & $\begin{array}{l}\text { Vacc + GM-CSF or } \\
\text { vacc + placebo or } \\
\text { placebo + placebo }\end{array}$ & NCT01322490 & OS \\
\hline ProstAtak & $\begin{array}{l}\text { AdV-tk (in situ tumor } \\
\text { killing) }\end{array}$ & Prostate & $\begin{array}{l}\text { Localized disease, } \\
\text { adjuvant to upfront } \\
\text { RT }\end{array}$ & $\begin{array}{l}\text { AdV-tk + val + RT +/- } \\
\text { ADT or placebo + val } \\
+ \text { RT + ADT }\end{array}$ & NCT01436968 & DFS \\
\hline POL-103A & $\begin{array}{l}\text { Polyvalent "shed" } \\
\text { antigens }\end{array}$ & Mel & $\begin{array}{l}\text { Adjuvant, stage IIb, } \\
\text { Ilc, III }\end{array}$ & $\begin{array}{l}\text { Vacc without API or } \\
\text { vacc }\end{array}$ & NCT01546571 & RFS \\
\hline GSK 2132231A & $\begin{array}{l}\text { MAGE-A3 fusion } \\
\text { protein }\end{array}$ & Mel & $\begin{array}{l}\text { Adjuvant, stage } \\
\text { III, macroscopic } \\
\text { involvement, } \\
\text { MAGE-A3 }\end{array}$ & $\begin{array}{l}\text { Immunotherapy or } \\
\text { placebo }\end{array}$ & NCT00796445 & DFS \\
\hline Stimuvax & $\begin{array}{l}\text { BLP25 liposome } \\
\text { (MUC1) }\end{array}$ & NSCLC & $\begin{array}{l}\text { Asian patients, } \\
\text { stage III with SD or } \\
\text { objective response }\end{array}$ & Vacc or L-BLP25 & NCT01015443 & OS \\
\hline Stimuvax & $\begin{array}{l}\text { BLP25 liposome } \\
\text { (MUC1) }\end{array}$ & NSCLC & $\begin{array}{l}\text { Stage III with SD or } \\
\text { objective response }\end{array}$ & $\begin{array}{l}\mathrm{CY}+\text { vacc followed by } \\
\text { vacc or placebo }\end{array}$ & NCT00409188 & $\begin{array}{l}\text { Survival } \\
\text { duration }\end{array}$ \\
\hline GV1001 & Peptide (telomerase) & NSCLC & $\begin{array}{l}\text { Stage III after } \\
\text { chemoRT }\end{array}$ & $\begin{array}{l}\text { Vacc + GM-CSF or } \\
\text { placebo }\end{array}$ & NCT01579188 & OS \\
\hline GSK $2132231 \mathrm{~A}$ & $\begin{array}{l}\text { MAGE-A3 fusion } \\
\text { protein }\end{array}$ & NSCLC & $\begin{array}{l}\text { Adjuvant, stage IB, } \\
\text { II, or IIIA, MAGE-A3 }^{+}\end{array}$ & $\begin{array}{l}\text { Immunotherapy or } \\
\text { placebo }\end{array}$ & NCT00480025 & DFS \\
\hline NeuVax & Peptide (HER2) & Breast & $\begin{array}{l}\text { Adjuvant, node- } \\
\text { positive, HER2 } \\
1+/ 2+, \text { HLA A2 or A3 }\end{array}$ & $\begin{array}{l}\text { Vacc + GM-CSF or } \\
\text { GM-CSF }\end{array}$ & NCT01479244 & DFS at $3 y$ \\
\hline GV1001 & Peptide (telomerase) & PDA & $\begin{array}{l}\text { Chemotherapy- } \\
\text { naïve, locally } \\
\text { advanced or } \\
\text { metastatic }\end{array}$ & $\begin{array}{l}\text { GX or GX followed by } \\
\text { vacc or GX + vacc }\end{array}$ & NCT00425360 & OS at $1 \mathrm{y}$ \\
\hline $\begin{array}{l}\text { Hyperacute- } \\
\text { pancreas }\end{array}$ & $\begin{array}{l}\text { Allo cell lines } \\
\text { expressing } \alpha \text {-gal }\end{array}$ & PDA & Adjuvant & $\begin{array}{l}\text { Gemcitabine +/- } \\
\text { chemoRT + vacc } \\
\text { or gemcitabine +/- } \\
\text { chemoRT }\end{array}$ & NCT01072981 & os \\
\hline DCVAX-L & DC (tumor lysate) & GBM & $\begin{array}{l}\text { After surgery \& } \\
\text { temozolomide- } \\
\text { based chemoRT }\end{array}$ & $\begin{array}{l}\text { Vacc or autologous } \\
\text { PBMC }\end{array}$ & NCT00045968 & PFS \\
\hline Rindopepimut & $\begin{array}{l}\text { EGFRvIll conjugated } \\
\text { to KLH }\end{array}$ & GBM & $\begin{array}{l}\text { After surgery \& } \\
\text { chemoRT in } \\
\text { EGFRvIll+ tumors }\end{array}$ & $\begin{array}{l}\text { Vacc + GM-CSF + } \\
\text { temozolomide or } \\
\text { KLH + temozolomide }\end{array}$ & NCT01480479 & os \\
\hline IMA901 & Multipeptide & Renal cell & $\begin{array}{l}\text { First-line metastatic } \\
\text { or locally advanced, } \\
\text { HLA-A*02+ }\end{array}$ & $\begin{array}{l}\mathrm{CY}+\text { vacc }+\mathrm{GM}-\mathrm{CSF}+ \\
\text { sunitinib or sunitinib }\end{array}$ & NCT01265901 & os \\
\hline \multicolumn{7}{|l|}{ Phase I/II } \\
\hline PROSTVAC & $\begin{array}{l}\text { Vaccinia/fowlpox } \\
\text { viruses (PSA) }\end{array}$ & mCRPC & Prior docetaxel & $\begin{array}{l}\text { 153Sm-EDTMP RT, RT } \\
+ \text { vacc + GM-CSF }\end{array}$ & NCT00450619 & 4-mo PFS \\
\hline PROSTVAC & $\begin{array}{l}\text { Vaccinia/fowlpox } \\
\text { viruses (PSA) }\end{array}$ & CRPC & $\begin{array}{l}\text { Localized prostate } \\
\text { cancer }\end{array}$ & $\begin{array}{l}\text { flutamide, } \\
\text { flutamide + vacc }\end{array}$ & NCT00450463 & TTF \\
\hline Provenge & $\begin{array}{l}\text { DC (PAP) + DNA } \\
(P A P)\end{array}$ & mCRPC & $\begin{array}{l}\text { Rising PSA or } \\
\text { progression on } \\
\text { imaging }\end{array}$ & $\begin{array}{l}\text { Provenge, Provenge } \\
+ \text { DNA vacc (pTVG-HP } \\
\text { + GM-CSF) }\end{array}$ & NCT01706458 & $\begin{array}{l}\text { Immune } \\
\text { response }\end{array}$ \\
\hline Provenge & DC (PSA) & mCRPC & $\begin{array}{l}\text { Rising PSA or } \\
\text { progression on } \\
\text { imaging }\end{array}$ & $\begin{array}{l}\text { Vacc or } \mathrm{CY}+\text { vacc }+ \\
\text { CT-011 (anti-PD-1) } \\
\text { or vacc }+ \text { CT-011 }\end{array}$ & NCT01420965 & Feasibility \\
\hline GVAX & $\begin{array}{l}\text { GM-CSF modified } \\
\text { whole cell }\end{array}$ & PDA & $\begin{array}{l}\text { Previously treated } \\
\text { metastatic \& } \\
\text { locally advanced }\end{array}$ & $\begin{array}{l}\text { Vacc }+ \text { ipilimumab } \\
\text { or ipilimumab }\end{array}$ & NCT00836407 & Safety \\
\hline $\begin{array}{l}\text { GVAX + CRS- } \\
207\end{array}$ & $\begin{array}{l}\text { GVAX + Listeria } \\
\text { (mesothelin) }\end{array}$ & PDA & $\begin{array}{l}\text { Previously treated } \\
\text { metastatic }\end{array}$ & $\begin{array}{l}\text { CY + GVAX or CY }+ \\
\text { GVAX followed by } \\
\text { CRS-207 }\end{array}$ & NCT01417000 & OS \\
\hline $\begin{array}{l}\text { Lovaxin } C \\
\text { regression }\end{array}$ & Listeria (E7) & Cervical & $\begin{array}{l}\text { Cervical } \\
\text { intraepithelial } \\
\text { neoplasia } 2 / 3 \\
\end{array}$ & $\begin{array}{l}\text { Low or middle } \\
\text { or high dose or } \\
\text { placebo }\end{array}$ & NCT01116245 & $\begin{array}{l}\text { Histologic } \\
\text { regression }\end{array}$ \\
\hline
\end{tabular}

Abbreviations: ADT, androgen deprivation therapy; adV-tk, adenovirus-thymidine kinase; $\alpha$-gal, alpha-galactosidase; allo, allogeneic; anti-PD-1, antiprogrammed death-1; API, active pharmaceutical ingredient; chemoRT, chemoradiation; CRPC, castrate-resistant prostate cancer; CY, cyclophosphamide; DC, dendritic cell; DFS, disease-free survival; EDTMP, ethylene diamine tetramethylene phosphonate; EGFRvlll, epidermal growth factor receptor variant III; GBM, glioblastoma multiforme; GM-CSF, granulocyte-macrophage colony-stimulating factor; GX, gemcitabine xeloda; HER2, human epidermal growth factor receptor; HLA, human leukocyte antigen; KLH, keyhole limpet hemocyanin; mCRPC, metastatic castrate-resistant prostate cancer; mel, melanoma; NSCLC, non-small cell lung cancer; OS, overall survival; PAP, prostatic acid phosphatase; PBMC, peripheral blood mononuclear cells; PDA, pancreatic adenocarcinoma; PFS, progression-free survival; PSA, prostate-specific antigen; pTVG-HP, plasmid DNA encoding human prostatic acid phosphatase; RFS, relapse-free survival; RT, radiotherapy; SD, stable disease; TTF, time to treatment failure; vacc, vaccine; val, valacyclovir. 
Le and Jaffee

pleted enrollment (ClinicalTrials.gov identifier: NCT01417000). An early analysis will be available in 2013. Theoretical advantages of combining a whole-cell vaccine approach with an $\mathrm{Lm}$ boost strategy include the targeting of a greater number of tumor antigens and the benefit of antibody induction. Pancreatic and prostate GVAX have been shown to induce antibodies to several proteins, including annexin A2, galectin-3, and PSMA. ${ }^{25,26}$ These proteins may have clinical relevance, because annexin A2 is thought to play a role in invasion and metastases of pancreatic cancer, galectin-3 promotes immune tolerance, and PSMA is expressed in more than half of prostate cancers. ${ }^{25,27,28}$

Lovaxin C (ADXS11-001, Lm-LLO-E7; Advaxis, Princeton, NJ) is based on a platform that incorporates the human papillomavirus E7 oncoprotein. The construct was studied in 15 subjects with previously treated, metastatic cervical carcinoma. ${ }^{24}$ E7-specific T-cell responses were detected in 1 of 3 subjects; $53 \%$ had stable disease (SD) and 30.8\% had tumor reduction. Lovaxin $\mathrm{C}$ is currently undergoing testing in patients with cervical intraepithelial neoplasia $2 / 3$. A second phase II study with Lovaxin $\mathrm{C}$ has been initiated for the treatment of persistent or recurrent cervical carcinoma (ClinicalTrials.gov identifier: NCT01266460). Next steps for the Lm vaccines will include multiepitope constructs and other combinatorial strategies.

\section{Selected Combinatorial Studies}

Several combination strategies have been proposed and tested to enhance the activity of vaccines. For tolerogenic tumors, in which spontaneous immune infiltrates are less common, a vaccine is likely necessary to induce antigen-specific $\mathrm{T}$ cells. For cancers that do have spontaneous immune infiltrates, combinations will likely make these $\mathrm{T}$ cells more effective. Synergistic strategies include combining vaccines with immune checkpoint inhibitors (eg, CTLA-4, PD-1), agents that target immunosuppressive cell populations (eg, regulatory $\mathrm{T}$ cells, myeloid-derived suppressor cells), standard chemotherapy or radiation, or other vaccines in a prime/ boost strategy (Figure 1). In particular, several studies have been reported in combination with ipilimumab, the inhibitor furthest along in development. Ipilimumab has been combined with both prostate GVAX ${ }^{26}$ and pancreatic GVAX (DTL, unpublished data, 2013). Both studies showed both tumor marker responses and objective CT scan responses. The prostate study was a dose-escalation study in mCRPC. The $3-\mathrm{mg} / \mathrm{kg}$ dose was expanded because of signs of clinical activity. In $25 \%$ of patients, $50 \%$ or greater PSA declines from baseline were observed. All of these patients received either 3 or $5 \mathrm{mg} / \mathrm{kg}$ of ipilimumab; $50 \%$ of the patients had SD on bone scan, and tumor regressions were seen. HLA-DR, a marker of T-cell activation, was

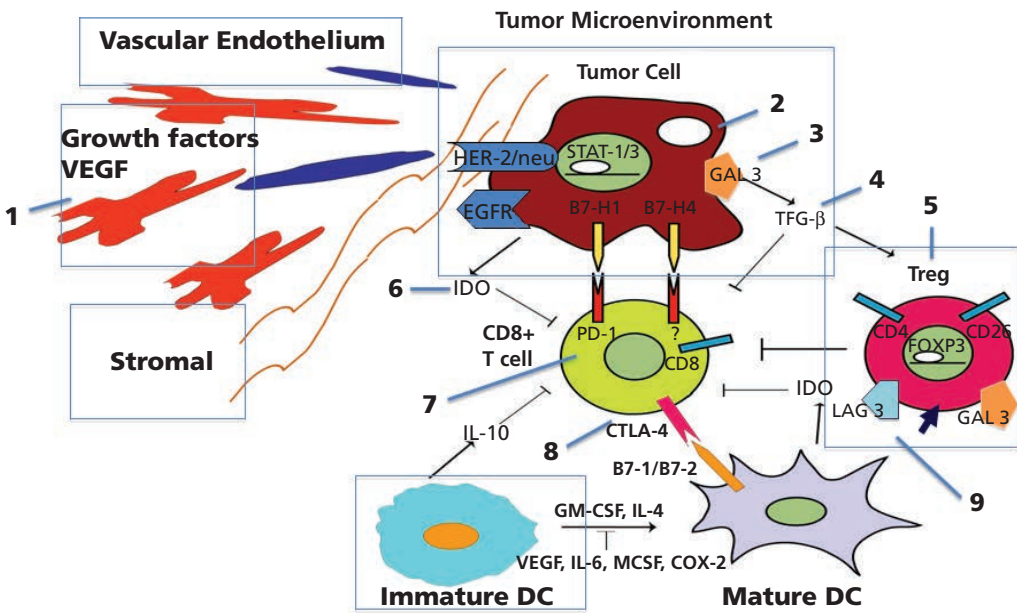

Figure 1 Combinatorial strategies simultaneously use vaccines to prime tumor antigen-specific T cells and other agents to block T-cell inhibitory signals. Commercial grade agents are available or will become available to test in combinations. Examples include: 1) bevacizumab; 2 ) celecoxib; 3 ) GCS-100; 4) GC-1008; 5) cyclophosphamide, daclizumab, denileukin diftitox; 6) 1-MT (methyl-tryptophan); 7) BMS-936558, BMS-936559, CT-011, MPDL3280A, MEDI4736, AMP-224, MK-3475; 8) ipilimumab, tremelimumab; and 9) BMS anti-lag-3.

Abbreviations: CTLA-4, cytotoxic T-lymphocyte antigen 4; DC, dendritic cell; EGFR, epidermal growth factor receptor; GM-CSF, granulocytemacrophage colony-stimulation factor; HER2, human epidermal growth factor receptor-2; IL, interleukin; PD-1, programmed death-1; VEGF, vascular endothelial growth factor 
only upregulated at the higher dose levels. Induction of PSMA-specific antibody responses was associated with improved OS. The median survival of the entire group was 29.2 months. The PSATricom vaccine was also combined with ipilimumab in a dose-escalation study in mCRPC. ${ }^{29}$ In chemotherapy-naïve patients, $14(58 \%)$ patients experienced a PSA decline, with 6 patients having PSA declines of $50 \%$ or greater. Median OS was 34.4 months and has not been reached for the chemotherapy-naïve patients. Both studies were small and uncontrolled, but nonetheless, the results are provocative.

The pancreatic GVAX study randomized patients with previously treated advanced pancreatic cancer to receive ipilimumab at $10 \mathrm{mg} / \mathrm{kg}$ with or without pancreatic GVAX. ${ }^{30}$ Despite having a small sample size, the survival benefit (5.7 vs 3.6 months; HR, $0.51 ; P=.072$ ) has meaning in the context of other signals of activity. Delayed SD and CT scan responses in association with declines in CA19-9 were only observed in patients receiving the combination therapy. Among patients with OS greater than 4.3 months, an increase in the peak mesothelin-specific $T$ cells $(P=.014)$ and enhancement of the T-cell repertoire $(P=.031)$ were seen. The repertoire was defined as the percentage of mesothelin peptides for which enhanced T-cell responses were measured. A randomized multicenter phase II study of this combination in patients who have been stabilized on chemotherapy is being pursued.

\section{Personalized Vaccines as a Potential for Future Combinations}

Although the development of powerful vaccine vectors continues to advance, efficacy in human clinical trials may be limited by the lack of proven immunogenic antigens that are meaningful in individual patients. Furthermore, targeting multiple antigens to minimize immune escape will likely be necessary. Increasingly efficient DNA sequencing methods along with optimization of vaccine vector technologies provide a unique opportunity to generate personalized vaccines integrating patient-specific tumor epitopes. Large-scale genomic analyses of a variety of tumor types have been completed. Most of the mutations are unique to an individual patient's tumor and not expressed by normal tissues. The mutations could generate a unique epitope that could be recognized by patient T cells. Studies in breast and colon cancer suggests that approximately 1 of every 10 mutations generates an HLA-A*0201binding epitope. ${ }^{31}$ Sequencing analysis of genomic DNA isolated from a series of pancreatic cancer cell lines suggests that pancreatic cancers accumulate an average of 63 genetic mutations. ${ }^{32}$ Panc 10.05, one of the cell lines used in GVAX, has undergone DNA sequencing analysis. Of the 54 somatic mutations identified, 16 of these were in genes confirmed to be expressed by the tumor cells. Furthermore, HLA-A*0201restricted mutant peptide-specific $\mathrm{CD}^{+} \mathrm{T}$ cells using ELISPOT assays were detected in 2 patients after treatment with the vaccine (E. Lutz, $\mathrm{PhD}$, unpublished data, 2012). Castle et $\mathrm{al}^{33}$ tested the question of whether the "mutanome" could identify antigens that can induce tumor-specific T-cell responses in a B16 murine melanoma model. Using next-generation sequencing exome resequencing, they identified nonsynonymous somatic point mutations in expressed genes in melanoma cells. Fifty mutations were tested through immunizing mice with long peptides. A third of these peptides were immunogenic. Peptide immunization resulted in tumor control in mice, showing that mutated peptides were immunogenic. As sequencing technologies and vaccine manufacturing are becoming more efficient, proposals are being developed to test these personalized strategies using peptide, DCs, and $L m$-based vaccines in clinical trials.

\section{Future of Vaccines}

Immunotherapy will undoubtedly continue to have an expanding role in cancer treatment. Although a great deal of interest has been shown in immune checkpoint inhibitors, they may not prove effective as a single agent in several cancers. Preclinical studies suggest that vaccines are necessary to induce tumor-specific $\mathrm{T}$ cells in the more immune-tolerant tumors. Thus, vaccine combinatorial strategies hold the greatest promise for clinical efficacy in larger groups of patients with multiple types of cancers. A great deal of need exists to optimize vectors, antigens, schedule of administration, combinations, and patient selection. However, investigators are poised to use the knowledge gained from prior studies and the explosion of antibody, vaccine vector, and sequencing technologies to move the field forward in a meaningful way for more patients. 
Le and Jaffee

\section{References}

1. Kantoff PW, Higano CS, Shore ND, et al. Sipuleucel-T immunotherapy for castration-resistant prostate cancer. N Engl J Med 2010;363:411-422.

2. Frohlich MW. Sipuleucel-T for the treatment of advanced prostate cancer. Semin Oncol 2012;39:245-252.

3. Lubaroff DM. Prostate cancer vaccines in clinical trials. Expert Rev Vaccines 2012;11:857-868.

4. Drake CG, Antonarakis ES. Current status of immunological approaches for the treatment of prostate cancer. Curr Opin Urol 2012;22:197-202.

5. Wolchok JD, Neyns B, Linette G, et al. Ipilimumab monotherapy in patients with pretreated advanced melanoma: a randomised, double-blind, multicentre, phase 2, dose-ranging study. Lancet Oncol 2010;11:155-164.

6. Hodi FS, O'Day SJ, McDermott DF, et al. Improved survival with ipilimumab in patients with metastatic melanoma. N Engl J Med 2010;363:711-723.

7. Singh N, Madan RA, Gulley JL. Ipilimumab in prostate cancer. Expert Opin Biol Ther 2013;13:303-313.

8. Brahmer JR, Drake CG, Wollner I, et al. Phase I study of singleagent anti-programmed death-1 (MDX-1106) in refractory solid tumors: safety, clinical activity, pharmacodynamics, and immunologic correlates. J Clin Oncol 2010;28:3167-3175.

9. Brahmer JR, Tykodi SS, Chow LQ, et al. Safety and activity of antiPD-L1 antibody in patients with advanced cancer. N Engl J Med 2012;366:2455-2465.

10. Topalian SL, Hodi FS, Brahmer JR, et al. Safety, activity, and immune correlates of anti-PD-1 antibody in cancer. N Engl J Med 2012;366:2443-2454.

11. Schuster SJ, Neelapu SS, Gause BL, et al. Vaccination with patientspecific tumor-derived antigen in first remission improves diseasefree survival in follicular lymphoma. J Clin Oncol 2011;29:27872794.

12. Schwartzentruber DJ, Lawson DH, Richards JM, et al. gp100 peptide vaccine and interleukin-2 in patients with advanced melanoma. N Engl J Med 2011;364:2119-2127.

13. Schlom J. Therapeutic cancer vaccines: current status and moving forward. J Natl Cancer Inst 2012;104:599-613.

14. Wolchok JD, Hoos A, O'Day S, et al. Guidelines for the evaluation of immune therapy activity in solid tumors: immune-related response criteria. Clin Cancer Res 2009;15:7412-7420.

15. Stein WD, Gulley JL, Schlom J, et al. Tumor regression and growth rates determined in five intramural $\mathrm{NCI}$ prostate cancer trials: the growth rate constant as an indicator of therapeutic efficacy. Clin Cancer Res 2011;17:907-917.

16. Sanda MG, Smith DC, Charles LG, et al. Recombinant vacciniaPSA (PROSTVAC) can induce a prostate-specific immune response in androgen-modulated human prostate cancer. Urology 1999;53:260-266.

17. Kantoff PW, Schuetz TJ, Blumenstein BA, et al. Overall survival analysis of a phase II randomized controlled trial of a Poxviralbased PSA-targeted immunotherapy in metastatic castrationresistant prostate cancer. J Clin Oncol 2010;28:1099-1105.

18. Gulley JL, Arlen PM, Madan RA, et al. Immunologic and prognostic factors associated with overall survival employing a poxviral-based PSA vaccine in metastatic castrate-resistant prostate cancer. Cancer Immunol Immunother 2010;59:663-674.

19. Halabi S, Small EJ, Kantoff PW, et al. Prognostic model for predicting survival in men with hormone-refractory metastatic prostate cancer. J Clin Oncol 2003;21:1232-1237.

20. Higano C, Saad F, Somer B, et al. A Phase III trial GVAX immunotherapy for prostate cancer versus docetaxel plus prednisone in asymptomatic, castration-resistant prostate cancer [abstract]. Presented at the 2009 Genitourinary Cancers Symposium; February 26-28, 2009; Orlando, Florida. Abstract LBA150 2009.

21. Small E, Demkow T, Gerritsen WR, et al. A phase III trial of GVAX immunotherapy for prostate cancer in combination with docetaxel versus docetaxel plus prednisone in symptomatic, castration-resistant prostate cancer [abstract]. Presented at the 2009 Genitourinary Cancers Symposium; February 26-28, 2009; Orlando, Florida. Abstract 7.

22. Le DT, Pardoll DM, Jaffee EM. Cellular vaccine approaches. Cancer J 2010;16:304-310.

23. Le DT, Brockstedt DG, Nir-Paz R, et al. A live-attenuated listeria vaccine (ANZ-100) and a live-attenuated listeria vaccine expressing mesothelin (CRS-207) for advanced cancers: phase I studies of safety and immune induction. Clin Cancer Res 2012;18:858-868.

24. Radulovic S, Brankovic-Magic M, Malisic E, et al. Therapeutic cancer vaccines in cervical cancer: phase I study of Lovaxin-C. J BUON 2009;14(Suppl 1):S165-168.

25. Zheng L, Foley K, Huang L, et al. Tyrosine 23 phosphorylationdependent cell-surface localization of annexin A2 is required for invasion and metastases of pancreatic cancer. PLoS One 2011;6:e19390.

26. van den Eertwegh AJ, Versluis J, van den Berg HP, et al. Combined immunotherapy with granulocyte-macrophage colony-stimulating factor-transduced allogeneic prostate cancer cells and ipilimumab in patients with metastatic castration-resistant prostate cancer: a phase 1 dose-escalation trial. Lancet Oncol 2012;13:509-517.

27. Hsu DK, Chen HY, Liu FT. Galectin-3 regulates T-cell functions. Immunol Rev 2009;230:114-127.

28. Mhawech-Fauceglia P, Zhang S, Terracciano L, et al. Prostatespecific membrane antigen (PSMA) protein expression in normal and neoplastic tissues and its sensitivity and specificity in prostate adenocarcinoma: an immunohistochemical study using mutiple tumour tissue microarray technique. Histopathology 2007;50:472483.

29. Madan RA, Mohebtash M, Arlen PM, et al. Ipilimumab and a poxviral vaccine targeting prostate-specific antigen in metastatic castration-resistant prostate cancer: a phase 1 dose-escalation trial. Lancet Oncol 2012;13:501-508.

30. Le DT, Lutz E, Uram JN, et al. Evaluation of Ipilimumab in combination with allogeneic pancreatic tumor cells transfected with a GM-CSF gene in previously treated pancreatic cancer. J Immunol, in press.

31. Segal NH, Parsons DW, Peggs KS, et al. Epitope landscape in breast and colorectal cancer. Cancer Res 2008;68:889-892.

32. Jones $\mathrm{S}$, Zhang $\mathrm{X}$, Parsons DW, et al. Core signaling pathways in human pancreatic cancers revealed by global genomic analyses. Science 2008;321:1801-1806.

33. Castle JC, Kreiter S, Diekmann J, et al. Exploiting the mutanome for tumor vaccination. Cancer Res 2012;72:1081-1091. 